\title{
Diagnostic exploration of enlarged peripheral nerves in suspected cases of leprosy. An analysis of 55 cases
}

\author{
DONG LIWEN, LI FUTIAN, GU ZHANGJING, \\ ZHANG JIALIN, CHEN JIAKUN, GU DAXIN, \\ WANG ZAIMING \& PENG JINHU \\ Zun Yi Hospital, Shanghai, China
}

Accepted for publication 3 February 1992

\begin{abstract}
Summary In 55 cases presenting with enlarged peripheral nerves without any skin lesions, a rice grain-sized biopsy of the nerve lesion was taken for histopathological examination. As a result definitive diagnoses could be established: leprosy was diagnosed in 32 cases. In 23 cases the cause of nerve enlargement was not leprosy: post-traumatic neuritis 9, cysts 5, hypertrophic neuritis 3 , nonspecific 4 , neurofibroma 1 , and amyloidosis 1 . In all of these cases there was a deficit of the nerve function and postoperatively there were no complications. The authors, as a result of this experience, believe that surgical exploration and biopsy is a harmless diagnostic tool for establishing a definitive diagnosis of leprosy in cases presenting with enlarged peripheral nerves without any skin lesions. In 23 out of 55 such cases the nerve enlargement was proved to be other causes than leprosy.
\end{abstract}

\section{Introduction}

The enlargement of peripheral nerves is one of the most important criteria for the diagnosis of leprosy. However, similar enlargements can also be caused by other peripheral nerve disorders, and this causes a problem in differential diagnosis in the absence of any other clinical manifestation of leprosy. We performed explorative surgery on the nerves of 55 such cases, and careful observations of the exposed nerve and histopathological examination of a very small biopsy of the nerve lesion established the correct diagnosis in all cases. This method and the results are presented and analysed in this communication.

\section{Materials and methods}

All the 55 patients studied had enlargement of peripheral nerves with a functional disturbance such as loss of superficial sensitivity, anhidrosis, muscle atrophy, clawed 
fingers or toes, footdrop and plantar ulcers. There were no skin lesions. Their ages ranged from 12 to 72 years ( 43 males and 12 females). The nerves involved were: 19 ulnar nerves, 8 median, 2 radial, 12 common peroneal, 1 posterior tibial and 15 cutaneous nerves, and 2 cases had bilateral enlargement of the ulnar nerves. The cutaneous nerves involved were the greater auricular (5), the superficial peroneal (5), the sural (2) and the antibrachial cutaneous (1), the infrapatellar branch of the saphenous (1), and the lateral cutaneous branch of the same nerve (1).

\section{METHOD OF SURGICAL EXPLORATION AND BIOPSY}

We explored the elbow for ulnar and median, the carpel tunnel for median, the radial groove in the upper arm for radial, around the neck of the fibula for common peroneal, the tarsal tunnel for the posterior tibial, and the sites of enlargement of the various cutaneous nerves.

Under local infiltration anaesthesia a longitudinal incision was made overlying the affected nerve, and the nerve exposed. Detailed observations were made on the shape and size of the nerve swelling; the appearance, colour, and thickness of the nerve sheath and its adhesions to the surrounding tissues and the condition of the surrounding structures. Any coexisting conditions such as injuries or other diseases causing deformity of bones, joints, fascia and nerve tunnel were specially looked for. Then a longitudinal incision was made in the nerve sheath. Observations were made on any change in internal pressure, adhesions between the epineurium and perineurium, the presence of any caseation, necrosis or fibrosis. A 'rice-grain' sized biopsy was taken from the nerve lesion through the epineurium and perineurium and examined histopathologically.

\section{Operative findings}

Caseation was found in 5 nerves, the elbow tunnel showed obvious marrowing in 5, while cysts were found in 5 . The fluid in the cysts was milky white. The shape of enlargement of the nerve was fusiform in the majority, beaded in some and uniform in others; 1 nerve had within it a neurofibroma. In all nerves there were adhesions between the epineurium and adjacent tissue, the extent being variable. There were 2 ulnar nerves showing dislocation at the elbow. Some nerves showed cysts distributed longitudinally.

\section{Histopathological findings}

The 32 cases diagnosed as leprosy by histopathology consisted of 10 cases of tuberculoid leprosy, 21 cases of borderline leprosy and 1 indeterminate case. In 12 of these cases AFB were demonstrated. The cyst wall in the 5 cases with neurilemmal cysts was made of collagen. In 3 nonleprosy cases the nerve showed hypertrophic neuritis. All cases showed a degeneration of the nerve to a varying extent. Amyloid change was seen in 1 case.

\section{Results}

The detailed results are shown in Table 1, and $32(58 \cdot 2 \%)$ out of 55 cases were diagnosed as leprosy. In 23 cases the causes of nerve enlargement varied from post-traumatic neuritis to neurilemmal cysts. Thus nerve exploration and a rice-grain-sized biopsy could establish diagnosis. 
Table 1.

\begin{tabular}{|c|c|c|c|c|c|c|c|}
\hline Nerve & Ulnar & Median & Radial & $\begin{array}{l}\text { Common } \\
\text { peroneal }\end{array}$ & $\begin{array}{l}\text { Posterior } \\
\text { tibial }\end{array}$ & $\begin{array}{l}\text { Cutaneous nerves including } \\
\text { greater auricular and } \\
\text { superficial peroneal }\end{array}$ & Total \\
\hline \multicolumn{8}{|l|}{ Disease } \\
\hline Leprosy & 8 & 6 & 1 & 6 & 1 & 10 & $32(58 \cdot 2 \%)$ \\
\hline $\begin{array}{l}\text { Post-traumatic } \\
\text { neuritis }\end{array}$ & 7 & & & 2 & & & 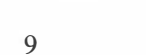 \\
\hline Neurile-mmal & & & & 5 & & & 5 \\
\hline Nonspecific & & & & & & & \\
\hline $\begin{array}{l}\text { neuritis } \\
\text { Hypertrophic }\end{array}$ & & & & 1 & & 3 & 4 \\
\hline $\begin{array}{l}\text { Hypertrophic } \\
\text { neuritis }\end{array}$ & & 2 & 1 & & & & 3 \\
\hline Neurofibroma & 1 & & & & & & 1 \\
\hline $\begin{array}{l}\text { Nerve } \\
\text { amyloidosis }\end{array}$ & 1 & & & & & & 1 \\
\hline Total & 17 & 8 & 2 & 14 & 1 & 13 & 55 \\
\hline
\end{tabular}

\section{Discussion}

One of the most important features of $M$. leprae is its predilection for peripheral nerve trunks. After entering the host through the skin or mucous membrane, the organisms probably spread centripetally from nerve ends to the nerve trunks. Specific interstitial mononeuritis or polyneuritis develops as a consequence. It may affect the nerve trunk, its primary branches or finer branches. The main clinical manifestation is nerve enlargement and disturbance of nerve function. Many cases of 'pure neuritic' leprosy occur where skin manifestations of the disease are absent. In these cases one or more nerves are enlarged with a variable amount of nerve dysfunction in its distribution. Often the diagnosis is in doubt. Exploration of the enlarged nerve together with biopsy is needed to establish diagnosis. Our results have shown that such an exploration and a rice-grain-sized biopsy indeed establishes diagnosis and has no harmful effect on the patient, because the biopsy is small and is taken from an already grossly affected portion of the nerve. In 23 of 55 cases reported here the cause of nerve enlargement was not leprosy. This is important to remember in order to avoid any wrong diagnosis. Diagnosis of leprosy often causes an adverse socioeconomic and psychological effect on the patient and his family. Wrong diagnosis is a calamity, an avoidable calamity. 


\title{
Exploration des nerfs périphériques hypertrophiés dans le diagnostic de cas suspectés de lèpre. Une analyse de 55 cas
}

\author{
Dong Liwen, Li Futian, Gu Zhanguing, Zhang Jialin, \\ Chen Jiakun, Gu Daxin, Wang Zaiming et Peng Jinhu
}

Résumé Dans 55 cas présentant une hypertrophie des nerfs sans lésions cutanées, une biopsie de la lésion nerveuse, de la taille d'un grain de riza été prélevée pour examen histopathologique. Des diagnostics définitifs ont pu ainsi être établis: la lèpre a été diagnostiquée dans 32 cas. Dans 23 cas, la cause de l'hypertrophie du nerf n'a pas été la peste, mais: névrite post-traumatique 9 cas, kystes 5 cas, névrite hypertrophique 3 cas, non spécifique 4 cas, neurofibrome 1 cas, et amylö̈dose 1 cas. Dans tous ces cas, un déficit de la fonction du nerf a été observé, et il n'y a pas eu de complication post-opératoire. Les auteurs, par suite de cette expérience, estiment que l'exploration chirurgicale et la biopsie constituent un outil de diagnostic sans danger pour établir un diagnostic de lèpre définitif dans les cas présentant une hypertrophie des nerfs periphériques sans lésions cutanées. Dans 23 des 55 cas présentant ces caractères, l'hypertrophie nerveuse s'est révélée être dûe à d'autres causes que la lèpre.

\section{La exploración diagnóstica de los nervios periféricos aumentados en los casos sospechados de lepra. Un análisis de 55 casos}

\author{
Dong Liwen, Li Futian, Gu Zhanguing, Zhang Jialin, \\ Chen Jiakun, Gu Daxin, Wang Zaiming y Peng Jinhu
}

Resumen En 55 casos en que se ha presentado nervios periféricos aumentados sin lesiones dérmicas, se tomó una biopsia del tamaño de un grano de arroz de la lesión del nervio, para un examen histopatológico. Por consecuencia, se pudieron establecer diagnósticos definitivos: se diagnosticó la lepra en 32 casos. En 23 casos, la causa del aumento de los nervios no fue leprosa: neuritis postraumática 9 , quistes 5 , neuritis hipertrófica 3 , no específicos 4, neurofibroma 1 y amiloidosis 1 . En todos estos casos, hubo un déficit de la función neurológica, y no hubieron complicaciones postoperativas. Como consecuencia de esta experiencia, los autores creen que la exploración quirúrgica y biopsia es un procedimiento diagnóstico inofensivo para el establecimiento de un diagnóstico definitivo de la lepra en aquellos casos que presentan nervios periféricos aumentados sin lesiones dérmicas. En 23 de 55 de tales casos, el aumento de los nervios resultó ser por razones distintas a la lepra. 